\title{
AKTIVITAS ANTIMITOSIS HASIL FRAKSINASI EKSTRAK KLOROFORM SPONS Siphanocalina sp TERHADAP SEL ZIGOT BULU BABI Tripneustus gratilla Linn.
}

\author{
Rina Agustina, Gemini Alam, Christiana Lethe \\ Fakultas Farmasi, Universitas Hasanuddin, Makassar
}

Kata Kunci :

Siphanocalina sp, antimitosis,

Tripneustus gratilla

\begin{abstract}
ABSTRAK
Kanker merupakan penyakit yang disebabkan karena ketidaknormalan pertumbuhan sel. Resistensi sel kanker pada beberapa jenis obat kanker serta efek samping obat yang begitu besar terhadap sel normal merupakan masalah dalam pengobatan kanker. Hal ini mendorong para peneliti untuk melakukan penelitian guna penemuan obat antikanker baru. Penelitian ini memanfaatkan biota laut yang diperoleh dari perairan di Sulawesi Selatan yaitu spons Siphanocalina sp yang bertujuan untuk mengetahui aktivitas antimitosis dari hasil fraksinasi ekstrak kloroform spons Siphanocalina sp. terhadap sel zigot Tripneustus gratilla Linn dan mengetahui golongan komponen kimia yang berperan dalam aktivitas antimitosis tersebut. Pengujian aktivitas antimitosis menggunakan sel zigot yang diperoleh dengan pembuahan sel telur dan sperma Tripneustus gratilla Linn yang dilakukan secara invitro. Sel zigot kemudian diberi perlakuan fraksi-fraksi hasil fraksinasi ekstrak kloroform dengan konsentrasi 100 $\mu \mathrm{g} / \mathrm{ml}$. Fraksi yang memiliki aktivitas penghambatan terbesar selanjutnya dilarutkan dengan pelarut etil asetat sehingga diperoleh subfraksi larut etil asetat dan tidak larut etil asetat. Selanjutnya, uji aktivitas subfraksi larut etil asetat dan tidak larut etil asetat dilakukan dengan konsentrasi 1, 10, dan $100 \mu \mathrm{g} / \mathrm{ml}$. Pembelahan sel diamati menggunakan mikroskop cahaya setelah 2 jam inkubasi. Dari hasil penelitian diperoleh bahwa fraksi tidak larut etil asetat memiliki aktivitas antimitosis yang kuat dengan nilai IC 50 $15,14 \mu \mathrm{g} / \mathrm{ml}$. Kontrol positif yang digunakan yaitu vinkristin dengan IC50 sebesar 0,183 $\mu \mathrm{g} / \mathrm{ml}$. Hasil identifikasi menggunakan kromatografi lapis tipis menunjukkan bahwa golongan senyawa kimia yang memiliki aktivitas antimitosis pada fraksi tidak larut etil asetat spons Siphanocalina sp diduga golongan alkaloida.
\end{abstract}

\section{PENDAHULUAN}

01-02-2017

$\begin{array}{ll}\text { Revisi } & 19-09-2017 \\ \text { Diterima } & 10-09-2017\end{array}$

DOI

http://dx.doi.org/10.20956/mff.v $21 \mathrm{i} 3.6855$

Korespondensi

Rina Agustina

rina_agustina84@yahoo.co.id

Fakultas Farmasi,

Universitas Hasanuddin,

Jalan Perintis

Kemerdekaan Km.10,

Makassar 90245,

Indonesia

Telp. $+62-411-588-556$

Fax. +62-411-585-188

Copyright

(C) 2017 Majalah Farmasi

Farmakologi Fakultas

Farmasi - Makassar

Diterbitkan tanggal

29-12-2017

Dapat Diakses Daring

Pada:

http://journal.unhas.ac.id

/index.php/mff
Kanker merupakan penyakit yang dapat dikenali dengan pertumbuhan dan penyebaran sel yang abnormal. Setiap tahun diperkirakan sekitar 6 juta pasien baru didiagnosa kanker di seluruh dunia (1). Di Indonesia, menurut hasil Riset Kesehatan Dasar Tahun 2013, sebanyak 1,4 dari 1000 penduduk Indonesia menderita kanker dan merupakan penyebab kematian nomor tujuh di Indonesia dengan presentasi $5,7 \%$ dari seluruh penyebab kematian. (2).

Biota laut khususnya spons merupakan salah satu sumber senyawa baru yang memiliki struktur yang unik dan memiliki berbagai aktivitas farmakologi. Beberapa senyawa kimia tersebut antara lain; Aaptamine yang diisolasi dari spons Aaptos sp memiliki aktivitas antiapoptosis dan antiproliferasi (3), Caliculin A yang diisolasi dari spons Dyscodermia calyx juga terbukti memiliki aktivitas antiproliferasi (4) Agosterol A yang berasal dari spons Spongia sp terbukti efektif terhadap sel kanker yang resisten terhadap vinkristin, colchisine, dan doxorubisin $(5,6)$, serta banyak lagi senyawa lainnya.

Uji aktivitas antikanker didasarkan atas adanya efek toksik pada sel (sitotoksik). Metode yang sering digunakan untuk aktivitas antikanker yaitu uji sitotoksisitas (7) Studi penghambatan pada perkembangan sel telur bulubabi merupakan model yang cocok untuk mendeteksi aktivitas sitotoksik, teratogenik, dan antineoplastik dari senyawa baru. Sel telur bulubabi juga digunakan secara luas sebagai model untuk mengevaluasi perkembangan toksikologi (8). Penghambatan pembelahan sel merupakan suatu ukuran aktivitas antimitotik dari senyawa kimia. Senyawa kimia yang bersifat antimitotik seperti vinblastine dan podophyllotoxin telah ditunjukkan penghambatannya terhadap pembelahan sel telur bulubabi setelah fertilisasi. Metode bioassay ini merupakan metode yang mudah untuk mendeteksi aktivitas senyawa kimia (9).

Berdasarkan studi yang dilakukan Alam, dkk (10), ekstrak kloroform spons Siphanochalina sp memiliki LC $50=245,9 \mu \mathrm{g} / \mathrm{ml}$ terhadap larva Artemia salina Leach. Hasil uji dikatakan toksik dengan metode BST apabila senyawa yang diujikan memiliki LC $50<1000 \mu \mathrm{g} / \mathrm{ml}$ (11). Aktivitas ketoksikan terhadap larva A. salina diduga berhubungan dengan kemampuan suatu senyawa dalam menghambat pembelahan sel telur bulubabi (Tripneustus gratilla Linn). Oleh karena itu, pada penelitian ini bertujuan untuk mengetahui aktivitas antimitosis dari hasil fraksinasi eksrak kloroform spons Siphanocalina sp. terhadap sel zigot Tripneustus gratilla Linn dan mengetahui golongan komponen kimia yang berperan dalam aktivitas antimitosis tersebut. 


\section{METODE PENELITIAN}

\section{Alat dan Bahan}

Alat-alat yang digunakan adalah aerator, chamber, corong pisah, kromatografi kolom cair vakum, lampu UV $254 \mathrm{~nm}$ dan $366 \mathrm{~nm}$, mikropipet (Socorex), mikroskop kamera (Nikon), oven listrik (Memmert), spoit $3 \mathrm{ml}$,, tabung mikro (eppendorf).

Sampel spons Siphanocalina sp diperoleh dari koleksi sampel Laboratorium Fitokimia Fakultas Farmasi Universitas Hasanuddin. Bahan lain yang digunakan antara lain; air laut bebas protozoa, air suling, etil asetat, etanol, n-heksan, $\mathrm{KCl} 10$ $\%$, kloroform, lempeng silika gel GF 254 (E.Merck), metanol, Na CMC $1 \%$, pereaksi Dragendorf, FeClᄀ3 $5 \%$, H2SO4 $10 \%$.

\section{Ekstraksi dan Partisi}

Ekstraksi dilakukan dengan tehnik maserasi menggunakan cairan penyari methanol.selama 1 x 24 jam dan penyarian dilakukan pengulangan sebanyak dua kali. Filtrat disaring dan diuapkan pelarutnya hingga diperoleh ekstrak methanol kental (7). Ekstrak methanol yang diperoleh selanjutnya dipartisi dengan kloroform- air menggunakan corong pisah. Ekstrak kloroform dikumpulkan dan diuapkan pelarutnya hingga diperoleh ekstrak kloroform (11).

\section{Fraksinasi Ekstrak Kloroform}

Ekstrak kloroform spons Siphanocalina sp. difraksinasi lebih lanjut menggunakan kromatografi kolom cair vakum dengan fase diam silika gel dan fase gerak Heksan; Heksan : Etil asetat (20:1, 15:1, 10:1, 5:1, 1:1), Etil asetat : Heksan (5:1), Etil asetat, Etil asetat : metanol (1:1), metanol. Fase gerak tersebut ditentukan berdasarkan profil KLT ekstrak kloroform spons Siphanocalina sp. Fraksi-fraksi yang diperoleh diuapkan kemudian di KLT. Fraksi yang memiliki kesamaan profil KLT digabung. Fraksi gabungan digunakan sebagai sampel uji aktivitas. Fraksi aktif yang diperoleh kemudian dilarutkan dengan etil asetat sehingga diperoleh subfraksi yaitu subfraksi larut dan tidak larut etil asetat. Kedua subfraksi ini diuji kembali aktivitasnya (12).

Uji Aktivitas dengan Metode Uji Antimitotik Sel Telur Bulubabi

\section{Penyiapan Sel Telur dan Sperma Bulubabli}

Bulubabi jantan dan betina diinduksi dengan dengan menyuntikkan $1 \mathrm{ml} \mathrm{KCl} 10 \%$ ke dalam bagian gonad. Sperma yang berwarna putih susu dan sel telur yang berwarna kuning keemasan ditampung pada gelas kimia yang berbeda. Fertilisasi dilakukan dengan cara $1 \mathrm{ml}$ sperma dan $4 \mathrm{ml}$ sel telur difertilkan dalam gelas kimia yang berisi $50 \mathrm{ml}$ air laut bebas protozoa (13).

\section{Penyiapan Sampel Uji}

Fraksi gabungan dari hasil kolom kromatografi cair vakum ekstrak kloroform spons Siphanocalina sp ditimbang sebanyak 10 mg kemudian disuspensikan dengan Na CMC sebanyak $10 \mathrm{ml}$ sehingga diperoleh konsentrasi $1000 \mu \mathrm{g} / \mathrm{ml}$ sebagai stok. Dari stok tersebut dipipet ke dalam tabung mikro dengan menggunakan mikropipet untuk mendapatkan konsentrasi $100 \mu \mathrm{g} / \mathrm{ml}$. Subfraksi larut dan tidak larut etil asetat masing-masing ditimbang $10 \mathrm{mg}$ kemudian disuspensikan dengan $10 \mathrm{ml} \mathrm{Na}$ CMC untuk subfraksi larut etil asetat sedangkan subfraksi tidak larut etil asetat dilarutkan dengan $10 \mathrm{ml}$ air suling sehingga diperoleh konsentrasi $1000 \mu \mathrm{g} / \mathrm{ml}$. Dari larutan stok ini dipipet menggunakan mikropipet ke dalam tabung mikro untuk mendapatkan konsentrasi 1,10, dan $100 \mu \mathrm{g} / \mathrm{ml}$. Kontrol negatif dibuat dua jenis yaitu kontrol air laut dan kontrol dengan menggunakan Na CMC konsentrasi $100 \mu \mathrm{g} / \mathrm{ml}$.
Kontrol positif menggunakan vinkristin dengan konsentrasi $0,01 \mu \mathrm{g} / \mathrm{ml}, 0,1 \mu \mathrm{g} / \mathrm{ml}$, dan $1 \mu \mathrm{g} / \mathrm{ml}$.

\section{Pelaksanaan Uji}

Tabung mikro yang berisi sampel ditambahkan air laut sesuai perhitungan untuk mencukupkan volume akhir $1 \mathrm{ml}$. Kemudian dalam tabung tersebut ditambahkan zigot sebanyak $100 \mu \mathrm{g} / \mathrm{ml}$ setelah 10 menit terjadinya fertilisasi. Dilakukan pengulangan 3 kali untuk tiap sampel uji dan kontrol. Selanjutnya disimpan pada suhu 15-20 o C dengan diselingi pengocokan. Pengamatan sel yang membelah dilakukan setelah 2 jam inkubasi (13).

\section{Pelaksanaan Uji}

Subfraksi I ditotolkan pada lempeng KLT kemudian dielusi dengan EtoAc : $\mathrm{MeOH}: \mathrm{NH}_{4} \mathrm{OH}(100: 20: 3$ tetes), kemudian kromatogramnya disemprot dengan menggunakan penampak noda sebagai berikut:

1. Pereaksi $\mathrm{H}_{2} \mathrm{SO}_{4} 10 \%$ : Kromatogram dipanaskan pada $105{ }^{\circ} \mathrm{C}$ selama 10 menit dan diamati ; kebanyakan senyawa organik memberikan warna kuning, coklat, atau hitam.

2. Pereaksi Dragendorf : Akan dihasilkan warna jingga dengan latar belakang kuning untuk senyawa golongan alkaloida.

3. Pereaksi $\mathrm{FeCl}_{3} 5 \%$ : akan dihasilkan warna hijau atau biru untuk senyawa golongan fenol.

\section{Analisis Data}

Data yang diperoleh dari hasil pengamatan diolah dengan menggunakan analisis probit.

\section{HASIL DAN PEMBAHASAN}

Pemisahan ekstrak kloroform spons Siphanocalina sp dengan metode KCV menghasilkan 12 fraksi yang selanjutnya digabung menjadi tiga fraksi berdasarkan kesamaan noda pada KLT. Ketiga fraksi tersebut diuji aktivitas antimitosis dengan konsentrasi $100 \mu \mathrm{g} / \mathrm{ml}$ dan menunjukkan aktivitas penghambatan pembelahan sel zigot bulu babi yang sangat besar. (Tabel 1).

\begin{tabular}{cc} 
Tabel 1. Hasil pengukuran pH sediaan \\
\hline Fraksi & $\begin{array}{c}\text { Persen Penghambatan } \\
\text { (\%) }\end{array}$ \\
\hline Fraksi I & 84,0 \\
Fraksi II & 91,6 \\
Fraksi III & 100,0 \\
\hline
\end{tabular}

Fraksi yang memiliki penghambatan terbesar yaitu fraksi III dengan persen penghambatan sebesar $100 \%$. Fraksi III tersebut selanjutnya dilarutkan dengan pelarut etil asetat sehingga diperoleh subfraksi tidak larut etil asetat (subfraksi I) dan subfraksi larut etil asetat (subfraksi II). Subfraksi I dan II selanjutnya diuji kembali dengan kon sentrasi 1, 10, dan, $100 \mu \mathrm{g} / \mathrm{ml}$. Hasil yang diperoleh (Tabel 2) menunjukkan subfraksi I memiliki penghambatan pembelahan sel yang sangat besar yaitu nilai IC50 sebesar 15,14 $\mu \mathrm{g} / \mathrm{ml}$. Penghambatan pembelahan sel dapat dilihat pada Gambar 1. Jika dibandingkan dengan senyawa vinkristin murni yang memiliki IC ${ }_{50}=0,183 \mu \mathrm{g} / \mathrm{ml}$ maka subfraksi I dari spons Siphanocalina sp memiliki potensi yang sangat besar untuk dikembangkan menjadi bahan baku obat antikanker.

Identifikasi dengan KLT terhadap subfraksi I spons Siphanochalina sp menunjukkan ada 2 noda pada sinar UV $254 \mathrm{~nm}$ dan juga 2 noda pada sinar UV $366 \mathrm{~nm}$. Dengan menggunakan reagen semprot $\mathrm{H}_{2} \mathrm{SO}_{4} \quad 10 \%$ juga menunjukkan 2 noda berwarna hitam. Sedangkan dengan reagen semprot Dragendorf menunjukkan 3 noda (Rf 0,215; 0,261 ; dan 0,369) yang berwarna jingga dengan latar kuning 
(hasil yang positif terhadap adanya senyawa nitrogen yang diduga sebagai senyawa golongan alkaloid). Dengan harga Rf yang berbeda tersebut menunjukkan bahwa dalam subfraksi tersebut terdapat sedikitnya 3 senyawa pada Siphanochalina sp. Penampak noda dengan $\mathrm{FeCl}_{3}$ memberikan hasil yang negatif terhadap senyawa fenol (Gambar 2)

Tabel 2. Penghambatan Pembelajan Sel oleh Subfraksi Isolat III

\begin{tabular}{cccc}
\hline Sampel & $\begin{array}{c}\text { Konsentrasi } \\
(\mu \mathrm{g} / \mathrm{ml})\end{array}$ & $\begin{array}{c}\text { Persen } \\
\text { penghambatan } \\
(\%)\end{array}$ & $\mathrm{IC}_{50}$ \\
\hline NaCMC & - & 0 & 0 \\
Kontrol air laut & - & 0 & 0 \\
Vinkristin & 0.01 & $2.6 \pm 0.29$ & \\
& 0.1 & $7.4 \pm 0.35$ & 0.183 \\
& 1 & $97.1 \pm 5.02$ & \\
Subfraksi I & 1 & $1.47 \pm 0.24$ & \\
& 10 & $10.79 \pm 1.07$ & 15.14 \\
& 100 & $98 \pm 1.7$ & \\
Subfraksi II & 1 & 0 & 0 \\
& 10 & 0 & 0 \\
& 100 & $2.49 \pm 0.25$ & \\
\hline & & &
\end{tabular}

A
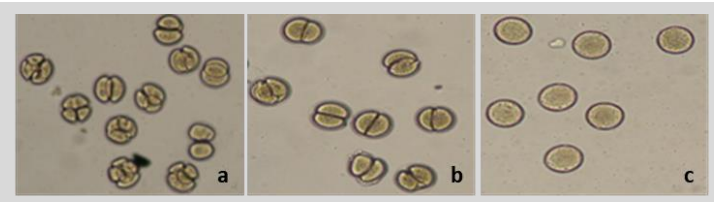

B

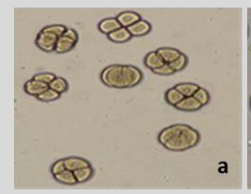

C

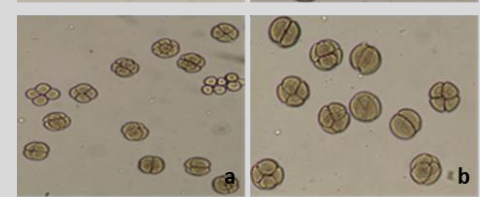

Gambar 1. Pembelahan Sel zigot Bulu Babi Setelah 2 jam perlakuan A Pembelahan sel zigot setelah pemberian subfraksi I spons Siphanochalina sp. a, b, dan c (Konsentrasi $1 \mu \mathrm{g} / \mathrm{ml}, 10 \mu \mathrm{g} / \mathrm{ml}$, dan ). B. Pembelahan sel zigot setelah pemberian Vinkristin. $a, b$, dan $c$ (Konsentrasi $0.01 \mu \mathrm{g} / \mathrm{ml} 0.1 \mu \mathrm{g} / \mathrm{ml}$, dan $1 \mu \mathrm{g} / \mathrm{ml}$ ), C. Kontrol negative. a. Kontrol air laut, b. NaCMC

Studi menunjukkan bahwa senyawa fitokimia menyebabkan gangguan mikrotubulus dan siklus sel. Alkaloid mengikat protein yang disebut tubulin selama pembelahan sel dan menghambat pembentukan tubulin (14). Steroid memblokir fase G2 / M dari siklus sel, menginduksi apoptosis, dan perubahan distribusi $\mathrm{Ca} 2+$ yang memicu pemecahan sitoplasma dalam sel somatik (15). Terpenoid memblokir mitosis dengan menstabilkan polimer tubulin yang selanjutnya menghambat pembongkaran mikrotubulus (16). Glikosida mengganggu pembentukan benang spindle yang menyebabkan kelainan selama tahap anafase (17) Aaptamines adalah salah satu senyawa golongan alkaloid yang memiliki aktivitas antikankeryang sangat baik, senyawa ini di isolasi dari spons Aaptos sp. (3)

Pada hewan bulu babi, mikrotubulus berperan penting dalam tahap embriogenesis. Mikrotubulus ini sangat penting dalam pemeliharaan bentuk, motilitas sel, transportasi intraseluler dan pembelahan sel (18). Mikrotubulus ini terbentuk dari subunit tubulin heterodimerik yang akan membentuk mikrotubulus multi-subunit ketika mengalami polimerisasi (19). Struktur ini yang mungkin dapat dipengaruhi oleh aktivitas antimitotik hasil fraksinasi ekstrak kloroform Siphanocalina sp.

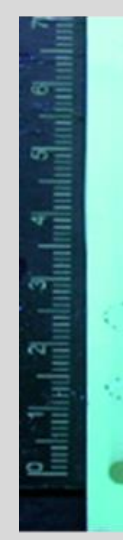

A

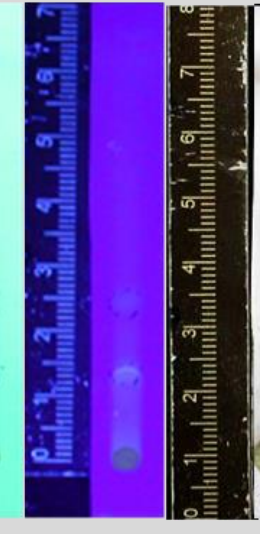

B

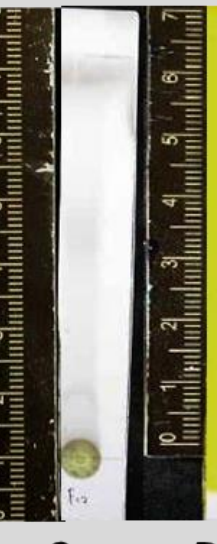

C

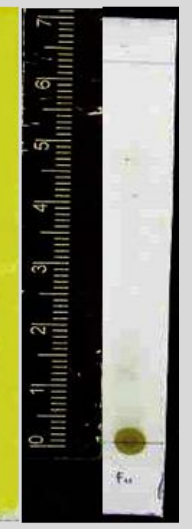

$\mathbf{E}$
Gambar 2. KLT Subfraksi Aktif. Subfraksi I (Subfraksi aktif) di KLT dengan menggunakan fase diam Lempeng KLT 60 PF254, fase gerak Etil asetat : methanol : $\mathrm{NH} 4 \mathrm{OH}$ (5:1: 3 tetes). Visualisasi : A. UV 254 nm, B. UV 366 nm, C. H2SO4 10 \%, D. Reagen Dragendorf , dan E. $\mathrm{FeCl}_{3}$

\section{KESIMPULAN}

Subfraksi I (tidak larut etil asetat) ekstrak kloroform spons Siphanochalina sp menunjukkan tingkat penghambatan pembelahan sel yang tinggi terhadap uji antimitosis sel zigot bulu babi (T. gratilla ) yaitu dengan IC $50=15,14 \mu \mathrm{g} / \mathrm{ml}$. Berdasarkan analisis KLT, senyawa kimia yang memiliki aktivitas antimitosis yang terdapat pada subfraksi I tersebut diduga golongan alkaloida

\section{DAFTAR PUSTAKA}

1. Anonymous. (2015). Cancer Facts \& Figures 2015. American Cancer Society.

2. Penyusun, T. (2014). Profil Kesehatan Indonesia 2013. Jakarta: Kementerian Kesehatan RI.

3. Dyshlovoy, S.A.; Fed orov, S.N.; Shubina, L.K.; Kuzmich, A.S.; Bokemeyer, C.; Keller-von Amsberg, G.; Honecker, F. Aaptamines from the marine sponge Aaptos sp. Display anticancer activities in human cancer cell lines and modulate ap-1-, Nf-kB-, and p53-dependent transcriptional activity in mouse jb6 cl41 cells. Biomed. Res. Int. 2014, 2014, 469309

4. Edelson, J.R.; Brautigan, D.L. The discodermia calyx toxin calyculin a enhances cyclin $\mathrm{d} 1$ phosphorylation and degradation, and arrests cell cycle progression in human breast cancer cells. Toxins 2011, 3, 105-119.

5. Aoki, S.; Chen, Z.S.; Higasiyama, K.; Setiawan, A.; Akiyama, S.; Kobayashi, M. Reversing effect of agosterol a, a spongean sterol acetate, on multidrug resistance in human carcinoma cells. Jpn. J.CancerRes. 2001, 92, 886895.

6. Chen, Z.S.; Aoki, S.; Komatsu, M.; Ueda, K.; Sumizawa, T.; Furukawa, T.; Okumura, H.; Ren, X.Q.; Belinsky, M.G.; Lee, K.; et al. Reversal of drug resistance mediated by multidrug resistance protein (mrp) 1 by dual effects of agosterol a on mrp1 function. Int. J. Cancer 2001, 93, 107-113

7. Mae, S.H.W., Mubarika, S., Ibnu Ganjar, G., Wahyuono, S. 2003. Pencarian Senyawa Antikanker Dari Bahan Alam. Majalah Obat Tradisional. Vol.8.No.26.: 1-3

8. Malpezzi ELA, Davino SC, Costa LV, Freitas JC, Giesbrecht AM \& Roque NF. 1994. Antimitotik action of extracts of Petiveria alliacea on sea urchin egg development. Brazilian Journal of Medica and Biological Research. Vol 27. 749.

9. Thomson, W.J., Rahman, A., Ginoudhary, M. I. 2001. Bioassay Techniques For Drug Development. Harword academic Publisher. Australia. 39-41

10. Alam,G., Syukur, R., Tahir,A., Sanusi,M., Khirlan. 2004. Skrining, Isolasi dan Identifikasi Struktur Senyawa Aktif Antimikroba \& Antikanker Beberapa Spons dari Perairan Laut Makassar . Laporan Riset Sains Dasar MIPA. Lembaga Penelitian UNHAS. 15

11. Alam,G., Syukur, R., Tahir,A., Sanusi,M., Khirlan. 2004. Skrining, Isolasi dan Identifikasi Struktur Senyawa Aktif Antimikroba \& Antikanker Beberapa Spons dari Perairan Laut Makassar . Laporan Riset Sains Dasar MIPA. Lembaga Penelitian UNHAS. 15

12. Costa-Latufo,L.V., Ferreira, M.A.D., Lemos, T.L.G., Pessoa,O.D.L .,Viana, G.S.B \& Cunha, G.M.A. 2002.Toxycity to sea urchin eggs development of the quinine fraction from Auxemma oncocalyx . Braz J. Med. Biol. Res .35(8). 1 


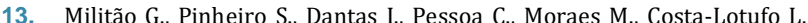
Lima M. and Silveira E. (2007). Bioassayguided fractionation of pterocarpans from roots of Harpalycebrasiliana Benth. Science Direct 6687-6691 Moudi M., Go R., Yong SeokYien C., Nazre M. (2013). Vinca Alkaloids. International Journal of Preventive Medicine, 4(11), US National Library of Medicine.

14. Hoffmannováa L., Oklešt'kováa J., Steigerováb J., Kohouta L., Kolář b Z and Strnada M. (2012). Anticancer Activities of Brassinosteroids. Practical Applications in Agriculture and Human Health, 84-93
15. Nagle A., Hur W. and Gray N.S. (2006). Antimitotic agents of Natural Origin. Curr. Drug Targets, 7 (3), 305-326

16. Tarkowska J. (2009). Antimitotic action of glycosides of Nerium oleander L. Wiley Online Library.

17. Bray D. (2001). Cell movements: from molecules to motility. 2nd edition. Garland publishing. New York.

18. Sconzo G., Romancino D., Fasulo G., Cascino D. and Giudice G. (1995) Effect of doxorubicin and phenytoin on sea urchin development. Pharmazie. 